\title{
ISLANDING OPERATION OF HYBRID MICRO-GRID SYSTEM WITH POWER MANAGEMENT CONTROL SCHEME
}

\author{
Mir Nahidul Ambia, Ahmed Al-Durra, Cedric Caruana, and S. M. Muyeen \\ The Petroleum Institute \\ Abu Dhabi, United Arab Emirates \\ mambia@pi.ac.ae, aaldurra@pi.ac.ae, ccaruana@pi.ac.ae and smmuyeen@pi.ac.ae
}

\begin{abstract}
In this paper, islanding operation of a hybrid micro-grid system is proposed with power management control scheme. When micro-grid system undergoes transition from grid connected to the islanded mode, it is required for the ac-dc based micro-grid system to provide adequate power to ac and dc loads connected in the system. Even when utility grid is disconnected from the micro-grid system, there is possibility of power imbalance in the system which may result in system instability. In this paper, control strategy of voltage source converter is presented which can maintain the terminal voltage of the micro-grid system constant during both grid connected and islanded modes. Another salient feature is the incorporation of power management control scheme which ensures the power management in the ac-dc based micro-grid system when it switches from grid connected to islanded mode or islanded mode to grid reconnected mode. The simulation results from PSCAD/EMTDC show that the micro-grid system may lose its stable operation without power management control scheme during islanded mode even if the voltage source converter is connected to the system. The effectiveness of the proposed control strategy is verified under three different scenarios.
\end{abstract}

\section{KEY WORDS}

Grid connected mode, islanding operation, micro-grid, photovoltaic system, power management, wind farm.

\section{Introduction}

At the growing demand of electricity, small modular generations like wind farm, photovoltaic system, fuel cell, batteries are internally connected to the distribution systems. This forms as an independent system interface as Micro-grid [1-2]. The micro-grid operates in two modes: grid connected and islanded mode. During the grid connected mode, the utility grid absorbs or delivers power from or to the micro-grid system. On the other hand, during islanded mode, small modular generations of the micro-grid system become the only source of energy for the load consumptions [3].

When the micro-grid system undergoes transition from grid connected to islanded mode, the terminal voltage needs to be maintained constant. The voltage closed-loop control for islanding operation is shown in [4]. Micro-grid autonomous operation during and subsequent to islanding process is mentioned in [5]. The voltage closed loop control keeps the terminal voltage of the micro-grid system constant during grid connected and islanded mode. But when utility grid is isolated from the micro-grid system, power delivery from the utility grid or power absorbing from the micro-grid suddenly becomes zero. This event causes the issue of imbalance of power in the system. The failure to ensure the power management in the system during the transition from grid connected to islanded mode or islanded mode to grid reconnected mode may result instability of micro-grid system.

In this study, voltage source converter control is proposed along with the power management control strategy. When micro-grid system is switched to the islanded mode, the power management control scheme change the converter power and power management can be performed by using dump load when there is surplus power or load shedding in the case of shortage of power in the micro-grid. The idea of dumping and shedding of load concept can be replaced with energy storage system, in a more meaningful way. According to the change of the dc load consumption, power management is ensured in the system. During the grid reconnection, the control scheme ensures again the power management in the system. Section 2 describes the proposed model system. Dynamic system modeling is shown in section 3. Control strategies of the voltage source converter and power management are demonstrated in section 4. The effectiveness of the proposed control scheme is shown under different scenarios in simulation section 5. Finally, conclusions are drawn in last section.

\section{Proposed Model System}

An ac-dc based hybrid micro-grid system has been proposed and shown in Fig. 1. The micro-grid consists of induction generator (IG) driven by fixed speed wind turbine as ac source and photovoltaic system, fuel cell as dc source. The hybrid micro-grid system has one ac bus and one dc bus. An ac-dc voltage source converter is connected in between the ac bus and dc bus along with transmission line $\mathrm{T}_{\mathrm{L} 1}$. The induction generator and one ac 
load are connected at the ac bus. The photovoltaic system, fuel cell, and one dc load are connected at the dc bus. Energy storage system is also connected at the dc bus as a back-up for the micro-grid system.

The utility grid is connected at the common coupling point $2\left(\mathrm{PCC}_{2}\right)$. The utility grid is connected via a circuit breaker $\left(\mathrm{C}_{\mathrm{Brk}}\right)$ and parallel connected transmission line $\mathrm{T}_{\mathrm{L} 3}$ and $\mathrm{T}_{\mathrm{L} 4}$ and step up transformer. $\mathrm{F}_{1}$ location is indicated as the point of fault. The photovoltaic system, fuel cell and energy storage system (ESS) is connected to the $\mathrm{dc}$ bus via individual $\mathrm{dc}-\mathrm{dc}$ converter. The photovoltaic system is connected with dc bus via dc-dc converter, so that maximum power can be extracted. Capacitor bank is used at the induction generator end point to maintain unity power factor operation at the rated wind speed. The parameters of the proposed micro-grid system and induction generator are shown in Table 1 and 2 , respectively.

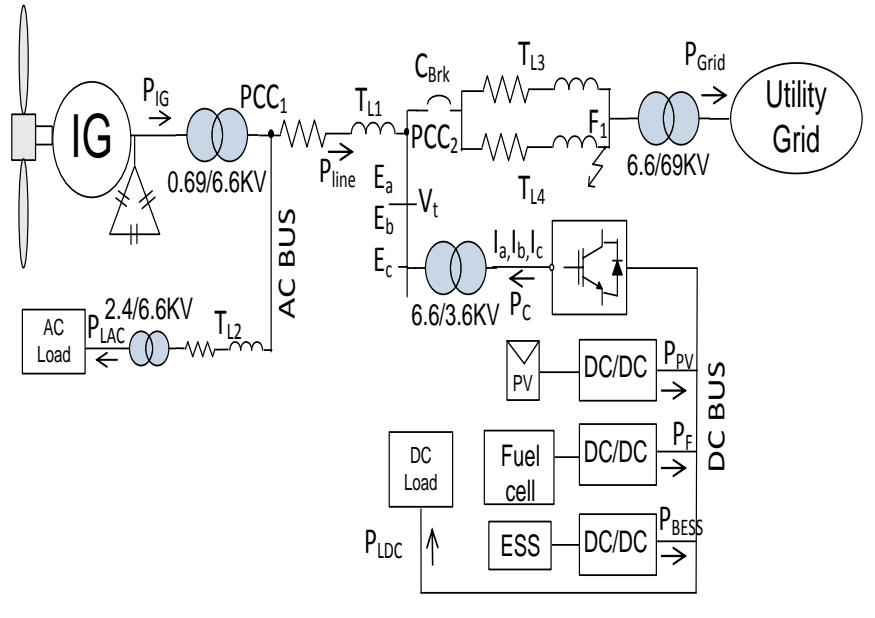

Fig. 1. Proposed micro-grid system.

The reactive power compensation at the wind generator terminal during low wind speed condition can be handled by the ac-dc voltage source converter. The current fed to the voltage source converter is shown as $I_{a}$, $\mathrm{I}_{\mathrm{b}}$ and $\mathrm{I}_{\mathrm{c}} . \mathrm{E}_{\mathrm{a}}, \mathrm{E}_{\mathrm{b}}$ and $\mathrm{E}_{\mathrm{c}}$ are the voltages at common coupling point $\left(\mathrm{PCC}_{2}\right)$ which is used as input to the phaselock-loop (PLL). The details of the converter control are shown in section 4 . As mentioned earlier, circuit breaker $\left(\mathrm{C}_{\mathrm{Brk}}\right)$ is connected at the utility grid side. During islanding operations such as maintenance or fault condition at the utility grid side, the circuit breaker $\left(\mathrm{C}_{\mathrm{Brk}}\right)$ trips and the utility grid gets disconnected from the microgrid system. During the islanding mode only induction generator (IG), photovoltaic system, and fuel cell operate as the source in the micro-grid system.

Table 1

Micro-grid parameters

\begin{tabular}{|l|l|}
\hline \multicolumn{1}{|c|}{ Parameters } & \multicolumn{1}{c|}{ Value } \\
\hline Base MVA of converter & $7 \mathrm{MVA}$ \\
\hline Base voltage of converter & $3.6 \mathrm{kV} \mathrm{V}$ \\
\hline Base current of converter & $1.1226 \mathrm{~A}$ \\
\hline Resistance $\left(\mathrm{T}_{\mathrm{L} 1}, \mathrm{~T}_{\mathrm{L} 3}\right.$ and $\left.\mathrm{T}_{\mathrm{L} 4}\right)$ & $0.26368 \Omega$ \\
\hline
\end{tabular}

\begin{tabular}{|l|l|}
\hline Inductance $\left(\mathrm{T}_{\mathrm{L} 1}, \mathrm{~T}_{\mathrm{L} 3}\right.$ and $\left.\mathrm{T}_{\mathrm{L} 4}\right)$ & $0.0004326 \mathrm{H}$ \\
\hline Length $\left(\mathrm{T}_{\mathrm{L}}, \mathrm{T}_{\mathrm{L} 3}\right.$ and $\left.\mathrm{T}_{\mathrm{L} 4}\right)$ & $2.06 \mathrm{~km}$ \\
\hline Resistance $\left(\mathrm{T}_{\mathrm{L} 2}\right)$ & $0.013312 \Omega$ \\
\hline Inductance $\left(\mathrm{T}_{\mathrm{L} 2}\right)$ & $0.00002184 \mathrm{H}$ \\
\hline Length $\left(\mathrm{T}_{\mathrm{L} 2}\right)$ & $104 \mathrm{~m}$ \\
\hline Total AC generation & $7 \mathrm{MW}$ \\
\hline Total DC generation & $0.5 \mathrm{MW}$ \\
\hline AC loads & Up to $2.5 \mathrm{MW}$ \\
\hline DC loads & Up to $3 \mathrm{MW}$ \\
\hline DC bus voltage & $1.5 \mathrm{kV}$ \\
\hline DC link capacitance & $100000 \mu \mathrm{F}$ \\
\hline
\end{tabular}

Table 2

Induction generator parameters

\begin{tabular}{|l|c|}
\hline \multicolumn{1}{|c|}{ Generator Type } & IGs \\
\hline MW & 7 \\
\hline Stator resistance & 0.01 \\
\hline Rotor resistance $(\mathrm{pu})$ & 0.01 \\
\hline Leakage reactance $(\mathrm{pu})$ & 0.1 \\
\hline Magnetizing reactance $(\mathrm{pu})$ & 3.5 \\
\hline Rotor mutual reactance $(\mathrm{pu})$ & 0.12 \\
\hline Inertia constant $(\mathrm{sec})$ & 1.5 \\
\hline Voltage rating, $\left(\mathrm{kV} \mathrm{V}_{\mathrm{LL}}\right)$ & 0.69 \\
\hline
\end{tabular}

The induction generator delivers 7MW and photovoltaic system generates $0.5 \mathrm{MW}$ amount of power [6]. The fuel cell and energy storage system is considered in the proposed micro-grid system; however, these are not considered in the simulation as the focus is mainly given in the islanding operation.

\section{Dynamic System Modeling}

\subsection{Wind turbine modeling}

Wind turbine is an electromechanical energy conversion device that is capable of capturing kinetic energy from the wind and can turn this energy into electrical energy. In order to model the wind turbine, its components consist of turbine rotor or prime mover, a shaft and a gearbox unit [7]. The wind turbine output torque and extracted power from the wind turbine can be expressed by following equations [8-9].

$$
\begin{aligned}
& T_{m}=\frac{1}{2} \cdot \rho C_{t}(\lambda) \pi R^{3} V_{W}{ }^{2}[N M] \\
& P_{m}=\frac{1}{2} \cdot \rho C_{P}(\lambda, \beta) \pi R^{2} V_{W}{ }^{3}[W]
\end{aligned}
$$

Where $\rho$ is the air density, $\mathrm{R}$ is the radius of the turbine, $V_{W}$ is the wind speed, $C_{P}(\lambda, \beta)$ is the power coefficient given by

$$
C_{P}(\lambda, \beta)=\frac{1}{2} \cdot\left(\Gamma-0.02 \beta^{2}-5.6\right) e^{-0.17 \Gamma}
$$

Where, $\Gamma=\frac{R(3600)}{\lambda(1609)}$ and $\lambda=\frac{\omega_{m} R}{V_{w}}$ is the tip speed
ratio. 
$\omega_{\mathrm{m}}$ represents the rotor mechanical speed and $\beta$ is the pitch of the rotor blades. The relationship between $C_{t}$ and $\mathrm{C}_{\mathrm{p}}$ is

$$
C_{t}(\lambda)=\frac{C_{P}(\lambda)}{\lambda}
$$

\subsection{Photovoltaic system modeling}

Each photovoltaic cell consists of a diode, a current source, a series resistance and a parallel resistance which is the basic element of a solar model. The photo current produced from the current source is dependent upon the solar cell radiation and temperature. The p-n junction of a solar cell is represented by the diode. The photovoltaic cell current equation can be expressed as [10]

$I_{P V}=n_{P} I_{P h}-n_{P} I_{r s}\left[e^{\left(\frac{q V_{d c}}{K T_{C} A n_{S}}\right)}-1\right]$

Where,

$I_{r s}=I_{r r}\left[\frac{T_{c}}{T_{r}}\right]^{3} e^{\left(\frac{q E_{g}}{K A}\right)\left(\frac{1}{T_{r}}-\frac{1}{T}\right)}$

$I_{p h}=0.01\left[I_{s c r}+K_{v}\left(T_{c}-T_{r}\right)\right] s$

Where, $n_{S}$ and $n_{P}$ are the number of cells connected in series and parallel respectively. $\mathrm{I}_{\mathrm{ph}}$ is the photo current, $\mathrm{I}_{\mathrm{rs}}$ and $I_{r r}$ are reverse saturation current at $T$ and $T_{r}$. $T$ is cell temperature and $T_{r}$ is reference temperature. $I_{\text {scr }}$ is the cell short circuit current at $T_{r}$. $S$ stands for irradiance in $\mathrm{mw} / \mathrm{cm}^{2} . \mathrm{K}$ is Boltzmann constant, $\mathrm{K}_{\mathrm{v}}$ is the short circuit temperature coefficient at $\mathrm{I}_{\mathrm{scr}}$ and $\mathrm{q}$ is charge of electron. $A$ is the identity factor. $I_{P V}$ is current from the photovoltaic cell.

\subsection{Fuel cell modeling}

Fuel cells are electrochemical devices which convert the chemical energy of a reaction into electrical energy. A fuel cell basically consists of an electrolyte layer (Ion conductor) in between a porous anode and cathode. Electric current is produced from the electrochemical reactions at the electrode, when gaseous fuel is injected to the anode and oxidant is fed to cathode [11].

\subsection{Energy storage system}

Energy storage is a device that stores energy and performs useful operation when by discharging it to the system. The energy storage system (ESS) nowadays is closely consociated with renewable energy sources such as photovoltaic or wind power applications even in microgrids. In case of excessive power generation, ESS can store the energy and can inject power to the system when the demand is greater or the generation is depleted. ESS can also be used to smooth the fluctuated wind farm output and deliver constant power to the grid [12].

\section{Control Strategy}

In the ac-dc based hybrid micro-grid system shown in Fig. 1 , ac-dc voltage source converter handles the reactive power compensation at the wind generator terminal. In this paper, controller of voltage source inverter is designed such a way so that it maintains the voltage at the point of common coupling $\left(\mathrm{PCC}_{2}\right)$ during grid connected, and islanded modes. When utility grid is disconnected from the system, real power from or to the utility grid becomes zero. This event causes imbalance of power in the system which may result in failure of fulfilling the load demand in the micro-grid system. To avoid these scenarios, real power through the voltage source converter and load consumption in the micro-grid system should be changed automatically, so that the power imbalance in the micro-grid system can be mitigated. In this section, control of voltage source converter and control strategy for power management are described in details.

\subsection{Voltage source converter}

Figure 2 shows the control block diagram of voltage source converter. The voltage source converter connected in between the ac and dc bus at the common coupling point $\left(\mathrm{PCC}_{2}\right)$ controls the real power flow between the ac and dc sides as well as controlling the terminal voltage $\mathrm{V}_{\mathrm{t}}$ at $\mathrm{PCC}_{2}$. As shown in the Fig. 2, $\mathrm{P}_{\text {Cref(pu) }}$ and $\mathrm{V}_{\mathrm{t}(\mathrm{ref})}$ are reference signals for the controllers. $\mathrm{P}_{\mathrm{C}}$ and $\mathrm{V}_{\mathrm{t}}$ are the measured signals from the micro-grid system as shown in Fig. 1. $\mathrm{P}_{\mathrm{C}(\mathrm{ref})}$ is the output of power management control block. The measured signals $\mathrm{P}_{\mathrm{C}}$ and $\mathrm{V}_{\mathrm{t}}$ are forced to track their references by using a PI controller. The outputs of the PI controller ( $I_{\text {dref }}$ and $I_{\text {qref }}$ ) are compared with the current $I_{d}$ and $I_{q}$ and the error is fed to a current regulator (PI controller). $\mathrm{E}_{\mathrm{dc}}$ and $\mathrm{E}_{\mathrm{qc}}$ are fed forwarded to the output of the PI controller to get a good dynamic response. Thus the voltage reference signals $\mathrm{E}_{\mathrm{d}}{ }^{*}$ and $\mathrm{E}_{\mathrm{q}}{ }^{*}$ are generated.

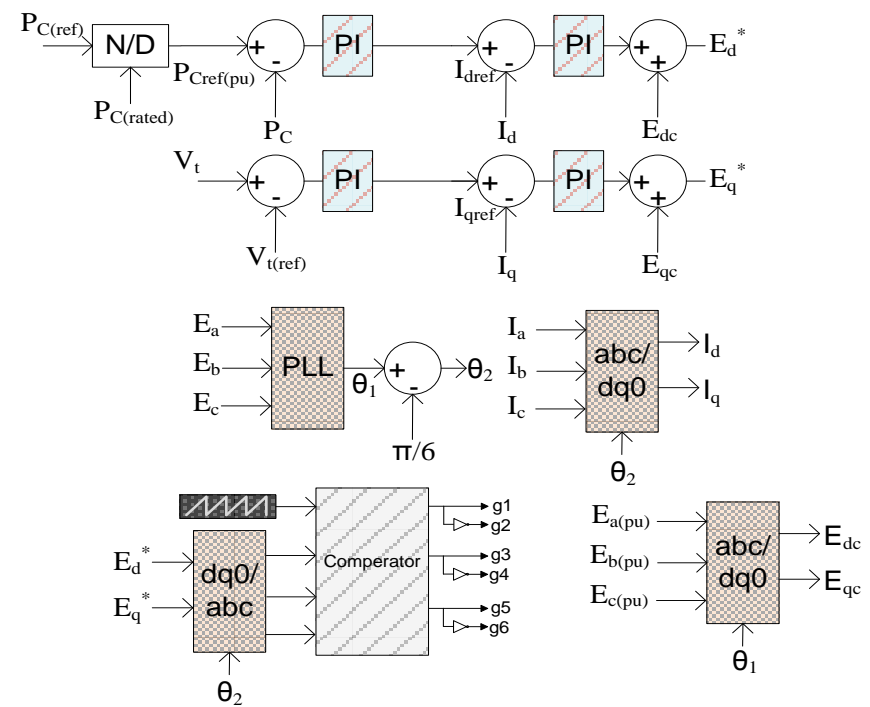

Fig. 2. Control block diagram of voltage source converter 
Measured currents $I_{a}, I_{b}$ and $I_{c}$ before the voltage source converter at the $3.6 \mathrm{kV}$ side of the transformer are transformed from abc-dq0. Thus $I_{d}$ and $I_{q}$ currents are generated. Angle $\theta_{2}$ is provided from the PLL to perform the abc-dq0 transformation. The $\mathrm{E}_{\mathrm{dc}}$ and $\mathrm{E}_{\mathrm{qc}}$ signals are generated by the transformation of abc-dq0. $\mathrm{E}_{\mathrm{d}}{ }^{*}$ and $\mathrm{E}_{\mathrm{q}}{ }^{*}$ are sent to the dq0-abc transformation block. The transformed voltage reference signals are sent to the pulse width modulation (PWM) signal generator to generate high-frequency gating signals for driving the three-phase voltage source converter. The necessary angle for the abc$\mathrm{dq} 0$ and dq0-abc transformation is provided by the PLL.

The transformation of three phase abc-dq0 and dq0 three phase abc is performed according to the following equations.

abc to dq0:

$\left[\begin{array}{l}d \\ q \\ 0\end{array}\right]=\frac{2}{3} \cdot\left[\begin{array}{ccc}\cos (\theta) & \cos \left(\theta-\frac{2 \pi}{3}\right) & \cos \left(\theta+\frac{2 \pi}{3}\right) \\ \sin (\theta) & \sin \left(\theta-\frac{2 \pi}{3}\right) & \sin \left(\theta+\frac{2 \pi}{3}\right) \\ \frac{1}{2} & \frac{1}{2} & \frac{1}{2}\end{array}\right] \cdot\left[\begin{array}{l}a \\ b \\ c\end{array}\right]$

dq0 to abc:

$\left[\begin{array}{l}a \\ b \\ c\end{array}\right]=\left[\begin{array}{ccc}\cos (\theta) & \sin (\theta) & 1 \\ \cos \left(\theta-\frac{2 \pi}{3}\right) & \sin \left(\theta-\frac{2 \pi}{3}\right) & 1 \\ \cos \left(\theta+\frac{2 \pi}{3}\right) & \sin \left(\theta+\frac{2 \pi}{3}\right) & 1\end{array}\right] \cdot\left[\begin{array}{l}d \\ q \\ 0\end{array}\right]$

\subsection{Power management}

During grid connected mode, the voltage source converter controls the terminal voltage $V_{t}$ and real power $\mathrm{P}_{\mathrm{C}}$ through the converter. However, when utility grid is disconnected from the micro-grid system, power management needs to be ensured in the system. In the control block diagram of the voltage source converter (Fig. 2), $\mathrm{P}_{\mathrm{C}(\mathrm{ref})}$ is mentioned as the reference signal for the real power $\mathrm{P}_{\mathrm{C}}$. When micro-grid switches from the grid connected mode to the islanded mode, the real power through the utility grid $\mathrm{P}_{\text {Grid }}$ becomes zero. At that time, the measured real power $\mathrm{P}_{\mathrm{C}}$ in the micro-grid system is required to change accordingly. For that reason, the reference signal $\mathrm{P}_{\mathrm{C}(\mathrm{ref})}$ of the controller of voltage source converter needs to be changed accordingly. The power management block generates the reference signal $\mathrm{P}_{\mathrm{C}(\mathrm{ref})}$ of the real power through converter and also generates required dc load consumption $\mathrm{P}_{\mathrm{Ldc}}$.

Figure 3, shows the control block of power management. The generated power from the induction generator $\mathrm{P}_{\mathrm{IG}}$, power through the utility grid $\mathrm{P}_{\text {Grid }}$ and ac load consumption is measured. During grid connected or on-grid mode, the reference $\mathrm{P}_{\mathrm{C}(\mathrm{ref})}$ of real power through the voltage source converter is calculated. The dc load consumption $\mathrm{P}_{\mathrm{Ldc}}$ for the particular grid connected mode is also calculated. When utility grid gets disconnected from the micro-grid system, the power management control block updates the reference signal $\mathrm{P}_{\mathrm{C}(\mathrm{ref})}$ and $\mathrm{dc}$ load consumption $\mathrm{P}_{\mathrm{Ldc}}$ by considering the grid power $\mathrm{P}_{\text {Grid }}$ as zero.

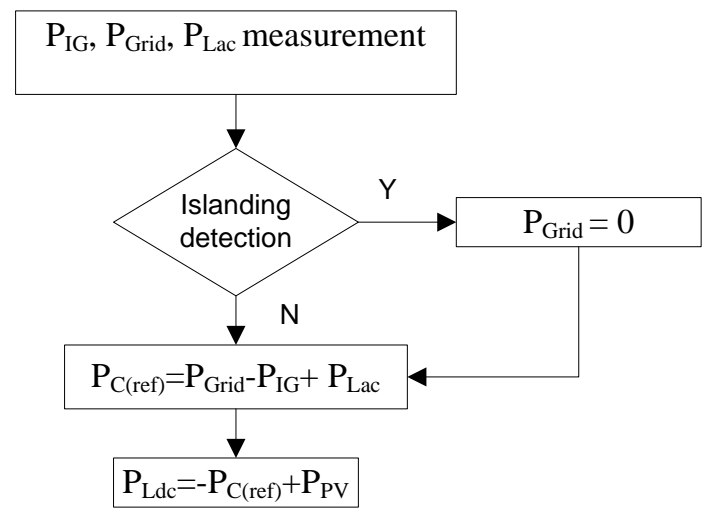

Fig. 3. Power management control block

A test case is considered in this paper for the verification of the power management control strategy. As mentioned earlier, induction generator extracts $\left(\mathrm{P}_{\mathrm{IG}}\right)$ $7 \mathrm{MW}$ and photovoltaic system $\left(\mathrm{P}_{\mathrm{PV}}\right)$ generates $0.5 \mathrm{MW}$ power. The test cases for grid connected mode and islanded mode are summarized in Table 3.

Table 3

On-grid and islanded mode scenarios

\begin{tabular}{|c|c|c|c|c|c|c|c|c|}
\hline Case & Mode & $\mathrm{P}_{\mathrm{IG}}$ & $\mathrm{P}_{\mathrm{PV}}$ & $\mathrm{P}_{\text {Lac }}$ & $\mathrm{P}_{\text {Grid }}$ & $P_{C(\text { ref })}$ & $\mathrm{P}_{\mathrm{Ldc}}$ & $P_{L d c}$ \\
\hline \multirow[t]{2}{*}{ 1(a) } & On-grid & \multirow{4}{*}{7} & \multirow{4}{*}{0.5} & \multirow[b]{2}{*}{3} & +0.5 & -3.5 & 4 & 0 \\
\hline & Islanded & & & & 0 & -4 & 4 & 0.5 \\
\hline \multirow[b]{2}{*}{$1(\mathrm{~b})$} & On-grid & & & & -0.5 & -3.5 & 4 & \multirow[t]{2}{*}{0} \\
\hline & Islanded & & & 4 & 0 & -3 & 3.5 & \\
\hline
\end{tabular}

In case 1(a), the utility grid absorbs real power from the micro-grid system and the ac load consumption is considered as 3MW. During the on-grid mode, the reference signal for the power through the voltage source converter is,

$$
\begin{aligned}
& \mathrm{P}_{\mathrm{C}(\mathrm{ref})}=\mathrm{P}_{\text {Grid }}-\mathrm{P}_{\mathrm{IG}}+\mathrm{P}_{\mathrm{Lac}}=0.5-7+3=-3.5 \mathrm{MW} \\
& \mathrm{P}_{\mathrm{Ldc}}+\mathrm{P}_{\mathrm{Ldc}} \text { Dump }=-\mathrm{P}_{\mathrm{C}(\mathrm{ref})}+\mathrm{P}_{\mathrm{PV}}=3.5+0.5=4 \mathrm{MW}
\end{aligned}
$$

During islanded mode, the $\mathrm{P}_{\text {Grid }}=0$.

$$
\begin{aligned}
& \mathrm{P}_{\mathrm{C}(\mathrm{ref})}=\mathrm{P}_{\text {Grid }}-\mathrm{P}_{\mathrm{IG}}+\mathrm{P}_{\mathrm{Lac}}=0-7+3=-4 \mathrm{MW} \\
& \mathrm{P}_{\mathrm{Ldc}}+\mathrm{P}_{\mathrm{Ldc} \text { Dump }}=-\mathrm{P}_{\mathrm{C}(\mathrm{ref})}+\mathrm{P}_{\mathrm{PV}}=4+0.5=4.5 \mathrm{MW}
\end{aligned}
$$

In case 1(b), the utility grid delivers real power to the micro-grid system. During on-grid mode, the reference signal for the power through the voltage source converter is,

$$
\begin{aligned}
& P_{C(\text { ref })}=P_{\text {Grid }}-P_{I G}+P_{L a c}=-0.5-7+4=-3.5 \mathrm{MW} \\
& P_{L d c}=-P_{C(\text { ref })}+P_{P V}=3.5+0.5=4 \mathrm{MW}
\end{aligned}
$$

During islanded mode, the $\mathrm{P}_{\text {Grid }}=0$.

$$
\begin{aligned}
& \mathrm{P}_{\mathrm{C}(\mathrm{ref})}=\mathrm{P}_{\text {Grid }}-\mathrm{P}_{\mathrm{IG}}+\mathrm{P}_{\mathrm{Lac}}=0-7+4=-3 \mathrm{MW} \\
& \mathrm{P}_{\mathrm{Ldc}}=-\mathrm{P}_{\mathrm{C}(\mathrm{ref})}+\mathrm{P}_{\mathrm{PV}}=3+0.5=3.5 \mathrm{MW}
\end{aligned}
$$


From the test case $1(a, b)$ it is seen that the power management control strategy calculates the reference signal of real power through the voltage source converter and required dc load consumption when micro-grid system changes from on-grid mode to the islanded mode. The reference signal is generated and updated in the converter control scheme so that during grid connected and islanded mode the power management is ensured in the system.

\section{Simulation results}

To verify the effectiveness of the proposed system, simulation analysis has been performed. The solution time step has been chosen to be $20 \mu$ s and channel plot step is $20,000 \mu \mathrm{s}$. The simulations have been performed by using PSCAD/EMTDC [13]. The effectiveness of the control scheme of voltage source converter and power management during grid connected, islanded mode, and grid reconnected mode is verified with different case analysis.

\subsection{Case1: Transition from utility grid connected to islanded mode with power management control scheme}

In case1, islanding operation is performed with power management control scheme to show the effectiveness of the entire control scheme. Test case shown in Table 3 is considered in the simulation.

\subsubsection{Case1 (a): Power flow from micro-grid to the utility grid during grid connected mode}

According to the test case, during grid connected mode, power flows from micro-grid to the utility grid. The utility grid absorbs real power from micro-grid system.

In Fig. 4, the responses of real power generation from the induction generator and photovoltaic system, ac and dc load consumption, power flow towards the utility grid, real power flow through the voltage source converter and terminal voltage are shown. The micro-grid system operates as grid connected mode up to $2 \mathrm{sec}$. The converter controls the real power and terminal voltage during grid connected mode. At $2 \mathrm{sec}$, the grid is disconnected from the system. From the figure, it is observed that real power flow through the converter changes from $3.5 \mathrm{MW}$ to $4 \mathrm{MW}$. The dc load is same but dump load is changed from 0MW to $0.5 \mathrm{MW}$ according to the power management control scheme. During both grid connected and islanded mode, power management is ensured in the whole micro-grid system. The ac load consumption is $3 \mathrm{MW}$ throughout the whole simulation. In Fig. 4(a), power generation from the induction generator (red color) is 7MW and photovoltaic system (blue color) is $0.5 \mathrm{MW}$. Figure $4(\mathrm{c})$ depicts that the utility grid is absorbing power from the micro-grid system during grid connected mode.
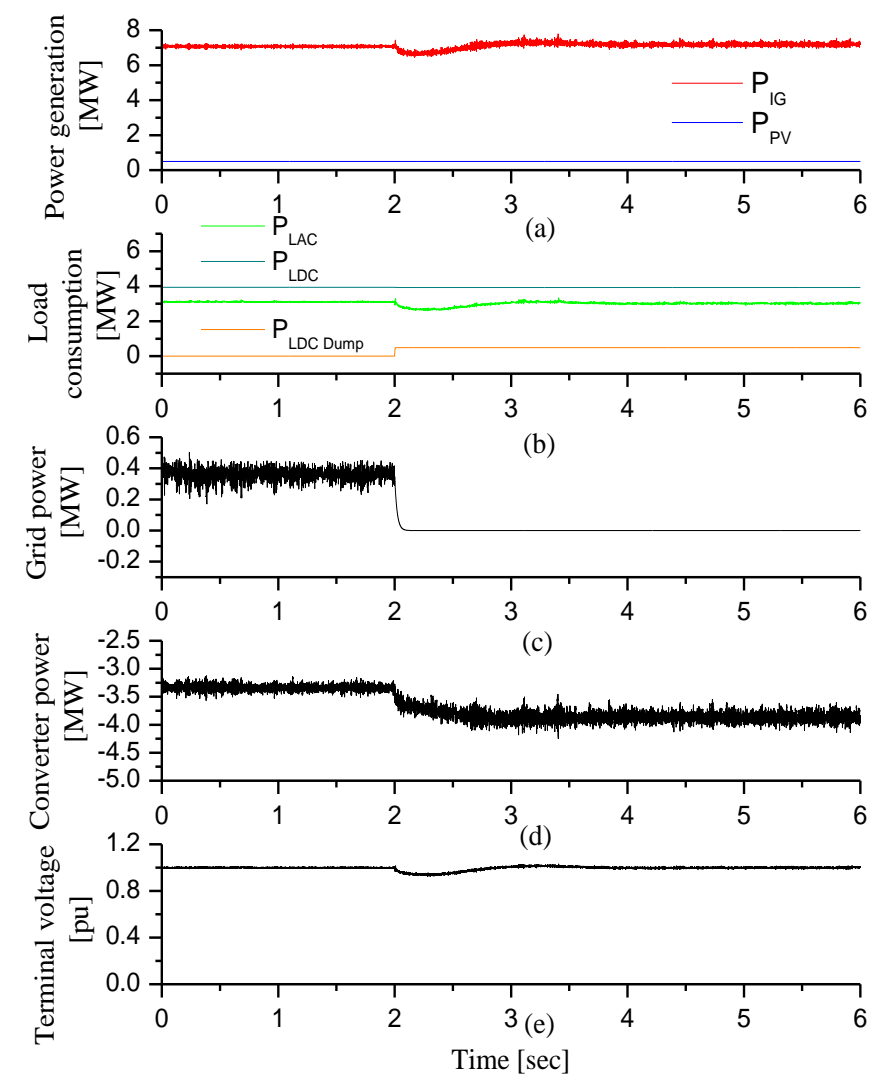

Fig. 4. System responses in Micro-grid system for case 1a (a) Power generations (b) Load consumption (c) Grid power (d) Power through converter (e) Terminal voltage

\subsubsection{Case1 (b): Power flow from utility grid to the} micro-grid during grid connected mode

In this test case, the utility grid delivers power to the micro-grid system.

Figure 5 depicts the response of power generation of induction generator and photovoltaic system, ac and dc load consumption, power flow from utility grid to the micro-grid system, real power through the voltage source converter and terminal voltage at common coupling point $\left(\mathrm{PCC}_{2}\right)$. Figure 5(c) shows that during grid connected mode, utility grid delivers power to the micro-grid system. Unlike the previous case, utility grid is disconnected at $2 \mathrm{sec}$ by an islanding operation. During the grid connected mode, the converter power is $3.5 \mathrm{MW}$ and $\mathrm{dc}$ load consumption is $4 \mathrm{MW}$. When grid is disconnected, the power management control scheme detects the islanding in the micro-grid system. In order to ensure the power management in the micro-grid system, the power management control block generates reference signals of $3 \mathrm{MW}$ for the voltage source converter. It is observed from Fig. 5(d) that the real power flow through the voltage source converter changes from $3.5 \mathrm{MW}$ to $3 \mathrm{MW}$. The dc load consumption is also changed to $3.5 \mathrm{MW}$ with load shedding of 0.5MW. In Fig. 5(e), it is observed that the terminal voltage at $\mathrm{PCC}_{2}$ is controlled to unity and the system stays stable during the islanded mode. 


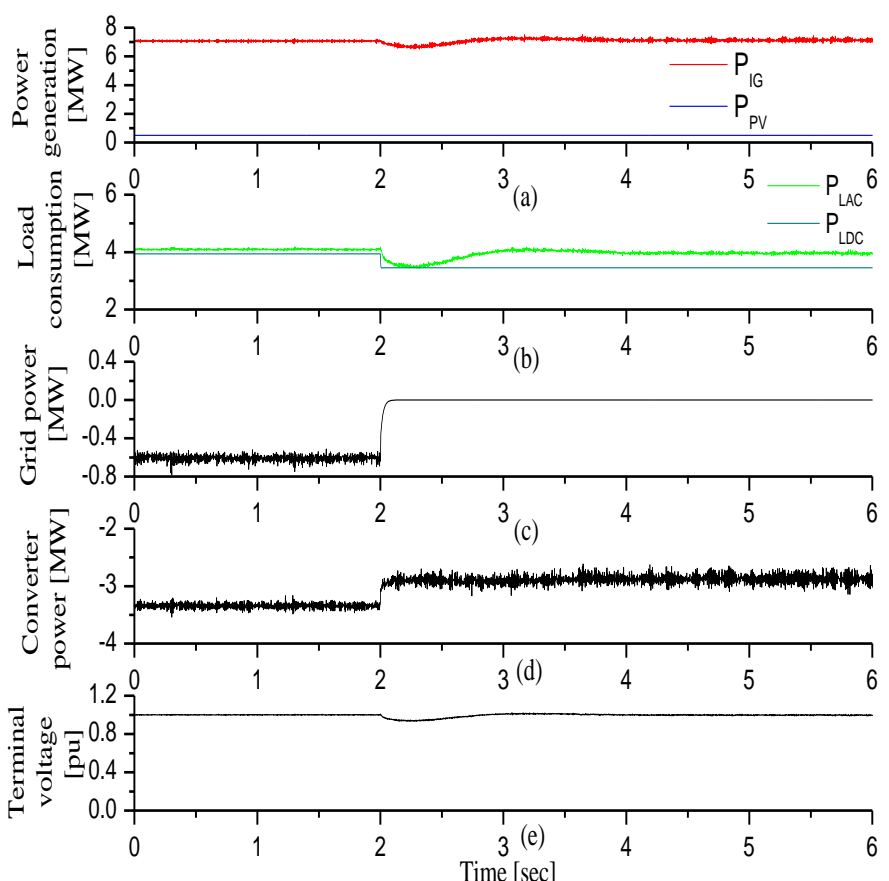

Fig. 5. System responses in Micro-grid system for case $1 b$ (a) Power generations (b) Load consumption (c) Grid power (d) Power through converter (e) Terminal voltage

\subsection{Case2: Transition from utility grid connected to islanded mode without power management control scheme}

In case 2 , transition from utility grid connected mode to the islanded mode is analyzed without considering the power management control scheme. Same test case conditions from case $1(\mathrm{a}, \mathrm{b})$ are repeated. In the simulation, it is shown that if the power management control scheme is not applied in the micro-grid system then the micro-grid system becomes unstable when grid is disconnected from the system.

In Fig. 6, case 2(a) is shown where utility grid absorbs power from the micro-grid system unlike case 1a, during grid connected mode. Utility grid is connected to the micro-grid system for first 2 seconds. During the grid connected mode the system is stable. At $2 \mathrm{sec}$, islanding operation is performed and grid is disconnected. As power management control is not applied in this case, the converter power is not changed and no dump load is used. For this reason, power management in the micro-grid system is hampered. In Fig. 6 (e), it is observed that terminal voltage cannot be controlled during the islanded mode. As a result, the whole micro-grid system collapses.

In Fig. 7, simulation responses of case 2(b) are shown where utility grid delivers power towards the micro-grid system. This case is also the repetition of case 1(b). Unlike case 2(a), power management control is not applied in this case. At $2 \mathrm{sec}$, islanding operation is performed. During islanded mode, power management is hampered. Figure 7(d) shows that the converter power is $3.5 \mathrm{MW}$ during grid connected and islanded mode. No load shedding is performed in the system. The terminal voltage is controlled during grid connected mode. But during islanded mode, the terminal voltage cannot be controlled. As a result the whole micro-grid system collapses.

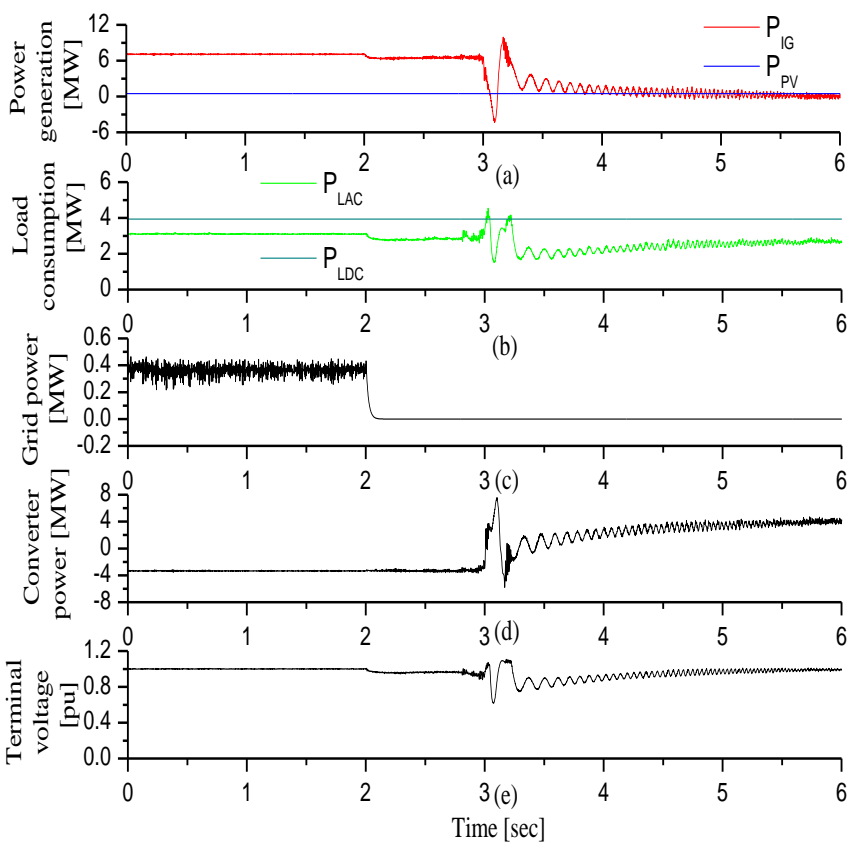

Fig. 6. System responses in Micro-grid system for case 2a (a) Power generations (b) Load consumption (c) Grid power (d) Power through converter (e) Terminal
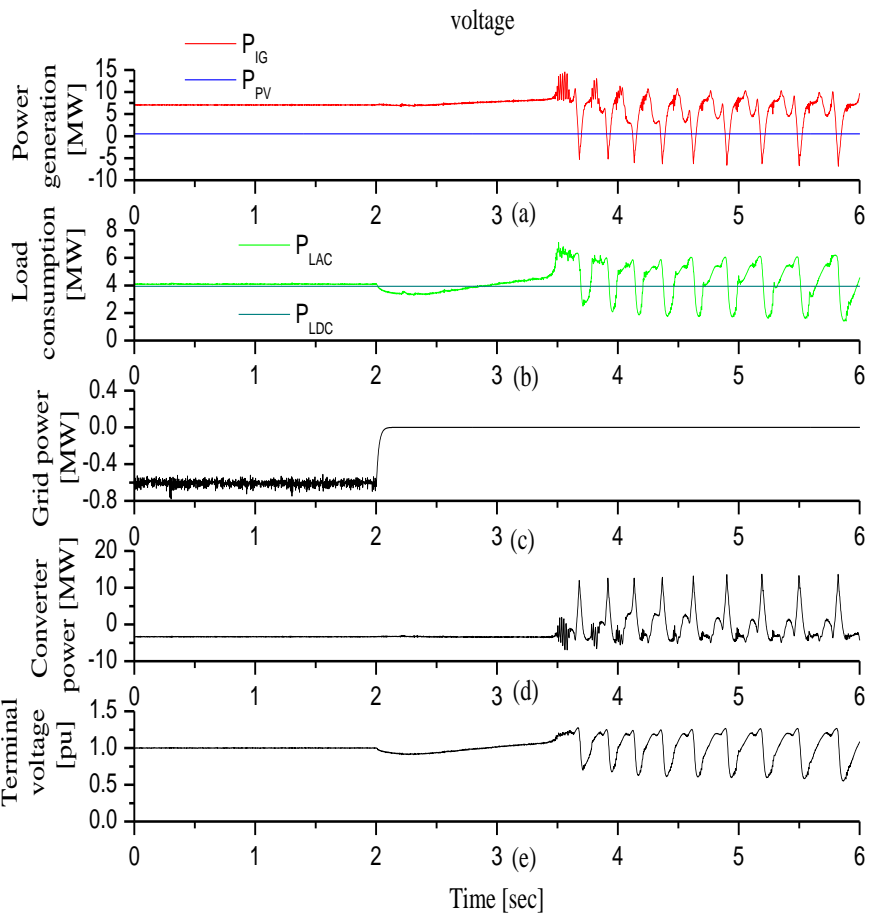

Fig. 7. System responses in Micro-grid system for case $2 b$ (a) Power generations (b) Load consumption (c) Grid power (d) Power through converter (e) Terminal voltage

5.3 Case 3: Line to ground fault at F1 location, transition from grid connected to islanded mode and utility grid reconnection.

In this case, a line to ground fault is considered in the transmission line $\mathrm{T}_{\mathrm{L} 4}$ at $\mathrm{F} 1$ location. The fault location is 
on the utility grid side. When fault occurs the utility grid is disconnected from the system. The effectiveness of the converter control and power management control is verified during the transition from grid connected to islanded mode and grid reconnection mode.

Line to ground fault (LG) occurs at $2 \mathrm{sec}$. The duration of the fault is 0.1 second. The fault is cleared at 2.083 second. The circuit breaker $\left(\mathrm{C}_{\mathrm{Brk}}\right)$ trip at 2.166 second and utility grid gets disconnected from the system. In Fig. 8, system responses of the micro-grid are shown. Figure 8(e) shows that after the grid fault and disconnection, the terminal voltage goes through a severe voltage dip. The real power through the converter changes from 3.5MW to 4MW (Fig. 8d), so that power management is ensured and thus terminal voltage is controlled during the islanded mode. The dump load is also used during the islanding mode. At $5 \mathrm{sec}$, the utility grid is reconnected to the micro-grid system. The converter power again changes from 4MW to $3.5 \mathrm{MW}$ and dump load of $0.5 \mathrm{MW}$ is turned off. This ensures the power management when grid is reconnected to the system. It is observed in Fig. 7 that the micro-grid is stable during both grid connected and islanded modes. The micro-grid system also operates efficiently when grid is reconnected to the system.

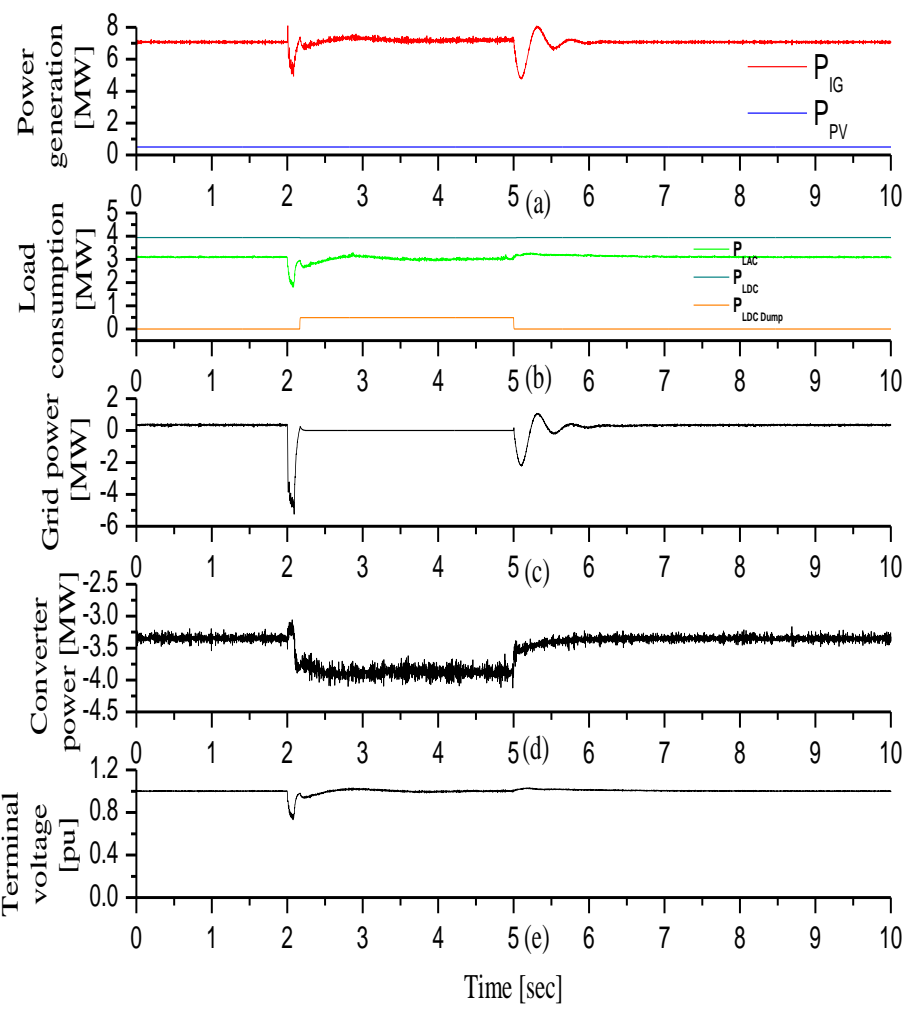

Fig. 8. System responses in Micro-grid system for case 3 with LG fault (a) Power generations (b) Load consumption (c) Grid power (d) Power through converter (e) Terminal voltage

\section{Conclusions}

The hybrid micro-grid system with voltage source converter control and power management control is proposed in this paper. The effectiveness of the proposed control scheme is verified by simulation analysis for different case scenarios. In the simulation section, it is shown that during grid connected and islanded modes, the voltage source converter control and power management control are capable of maintaining the terminal voltage constant. If utility grid delivers or absorbs power to or from micro-grid system, the micro-grid system still stays stable during transition from grid connected to islanded mode. Also it is shown in the simulation that if power management control is not considered in the micro-grid system then the voltage source converter fails to keep the micro-grid system stable. The power management is performed by adding a dump load or causing load shedding. An ESS can be used to perform the same task in a meaningful way; however, dump-load and load shedding techniques are adopted in this system for simplicity. Apart from the islanding, line to ground fault is also considered at the utility grid side location. During this transient case, when micro-grid switches from grid connected to islanded mode and islanded mode to grid reconnected mode, the proposed control scheme keeps the micro-grid system stable. It can be concluded that the control operation of voltage source converter and power management scheme performs the islanding operation and grid reconnection in a precise way and augments as well the stability of the system.

\section{References}

[1] Anne-Marie Borbely and Jan F. Kreider, Distributed Generation: Power Paradigm for the New Millennium; CRC Press., 2001.

[2] R. H. Lasseter, "MicroGrids," PES Winter Meeting, vol. 1, pp. 305-308, 2002.

[3] A. Burgio, D.Menniti and N. Sorrentino, The reliability studies of a novel integrated configuration for micro-grids, International conference on Electric Utility Deregulation and Restructuring and Power Technologies, pp-2634-2639, 6-9 April 2008.

[4] Irvin J. Balaguer, Q. Lei, Shuitao Yang, U. Supatti and F. Z. Peng, Control for grid-connected and intentional islanding operations of distributed power generation, IEEE Trans. on Industrial Electronics, Vol. 58, No. 1, January 2011, 147-157.

[5] F. Katiraei, M. R. Iravani and P. W. Lehn, Micro-grid Autonomous Operation During and Subsequent to Islanding Process, IEEE Trans. on Power Delivery, Vol. 20, No 1, January 2005, 248-257.

[6] M. N. Ambia, A. Al-Durra, and S.M. Muyeen, Centralized power control strategy using multi-converter shceme, IECON 2011-37 th Annual conference on IEEE industrial electronics society.

[7] S. Santos, and H. T. Le, "Fundamental Time-Domain Wind Turbine Models for Wind Power Studies,"Renewable Energy, Vol. 32, pp. 2436-2452, 2007.

[8] K.E. Okedu, S.M. Muyeen, R. Takahashi, and J. Tamura, "Comparative Study between Two Protection Schemes for DFIG-based Wind Generator, Proceedings 
of International Conference on Electrical Machines and Systems, pp. 62-67, 10-13 Oct. 2010.

[9] R. Takahashi, J. Tamura, M. Futami, M. Kimura and K. Idle, A New Control Method for Wind Energy Conversion System Using Double Fed Synchronous Generators, IEEJ Trans. Power and Energy, Vol.126, No.2, pp.225-235, 2006 (in Japanese).

[10] G. Vachtsevanos and K. Kalaitzakis, "A Hybrid Photovoltaic Simulator for Utility Interactive Studies," IEEE Trans. Energy Conversion, Vol. EC-2, No. 2, pp. 227-231, June 1987.

[11] M.J Khan and M. T. Iqbal, "Dynamic Modeling and Simulation of a Small Wind-Fuel Cell Hybrid Energy System," Renewable Energy, pp. 421-439,2005.

[12] S. M. Muyeen, J. Tamura, and T. Murata, "Stability Augmentation of a Grid-connected Wind Farm," Springer-Verlag London, ISBN 978-1-84800-315-6, October 2008.

[13] "PSCAD/EMTDC Manual," Manitoba HVDC Research Center, 1994. 